\title{
Quinine, an old anti-malarial drug in a modern world: role in the treatment of malaria
}

\author{
Jane Achan ${ }^{1 *}$, Ambrose O Talisuna ${ }^{2}$, Annette Erhart ${ }^{3}$, Adoke Yeka ${ }^{4}$, James K Tibenderana ${ }^{5}$, Frederick N Baliraine ${ }^{6}$, \\ Philip J Rosenthal ${ }^{6}$ and Umberto D'Alessandro ${ }^{3}$
}

\begin{abstract}
Quinine remains an important anti-malarial drug almost 400 years after its effectiveness was first documented. However, its continued use is challenged by its poor tolerability, poor compliance with complex dosing regimens, and the availability of more efficacious anti-malarial drugs. This article reviews the historical role of quinine, considers its current usage and provides insight into its appropriate future use in the treatment of malaria. In light of recent research findings intravenous artesunate should be the first-line drug for severe malaria, with quinine as an alternative. The role of rectal quinine as pre-referral treatment for severe malaria has not been fully explored, but it remains a promising intervention. In pregnancy, quinine continues to play a critical role in the management of malaria, especially in the first trimester, and it will remain a mainstay of treatment until safer alternatives become available. For uncomplicated malaria, artemisinin-based combination therapy (ACT) offers a better option than quinine though the difficulty of maintaining a steady supply of ACT in resource-limited settings renders the rapid withdrawal of quinine for uncomplicated malaria cases risky. The best approach would be to identify solutions to ACT stock-outs, maintain quinine in case of ACT stock-outs, and evaluate strategies for improving quinine treatment outcomes by combining it with antibiotics. In HIV and TB infected populations, concerns about potential interactions between quinine and antiretroviral and anti-tuberculosis drugs exist, and these will need further research and pharmacovigilance.
\end{abstract}

\section{Background and historical perspective}

The discovery of quinine is considered the most serendipitous medical discovery of the 17th century [1] and malaria treatment with quinine marked the first successful use of a chemical compound to treat an infectious disease[2]. Quinine, as a component of the bark of the cinchona (quina-quina) tree, was used to treat malaria from as early as the 1600 s, when it was referred to as the "Jesuits' bark," "cardinal's bark," or "sacred bark." These names stem from its use in 1630 by Jesuit missionaries in South America, though a legend suggests earlier use by the native population[2]. According to this legend, an Indian with a high fever was lost in an Andean jungle. Thirsty, he drank from a pool of stagnant water and found that it tasted bitter. Realizing that the water had been contaminated by the surrounding quina-quina trees he thought he was poisoned.

\footnotetext{
* Correspondence: achanj@yahoo.co.uk

'Department of Pediatrics and Child Health, Makerere University College of Health Sciences, P.O. Box 7475, Kampala, Uganda

Full list of author information is available at the end of the article
}

Surprisingly, his fever soon abated, and he shared this accidental discovery with fellow villagers, who thereafter used extracts from the quina-quina bark to treat fever [3]. The legend of quinine's discovery accepted in Europe differs though, and involves the Spanish Countess of Chinchon who, while in Peru, contracted a fever that was cured by the bark of a tree. Returning to Spain with the bark, she introduced quinine to Europe in 1638 and, in 1742, botanist Carl Linnaeus called the tree "Cinchona" in her honour [4].

Before 1820, the bark of the cinchona tree was first dried, ground to a fine powder, and then mixed into a liquid (commonly wine) before being drunk. In 1820, quinine was extracted from the bark, isolated and named by Pierre Joseph Pelletier and Joseph Caventou. Purified quinine then replaced the bark as the standard treatment for malaria [5]. Quinine and other cinchona alkaloids including quinidine, cinchonine and cinchonidine are all effective against malaria. The efficacies of these four alkaloids were evaluated in one of the earliest clinical trials, conducted from 1866 to 1868 in 3600

\section{Biomed Central}


patients using prepared sulfates of the alkaloids. With the main outcome measure of "cessation of febrile paroxysms", all four alkaloids were found to be comparable, with cure rates of $>98 \%[6]$. However, after 1890 quinine became the predominantly used alkaloid, mainly due to a change in supply from South American to Javan cinchona bark, which contained a higher proportion of quinine [7]. Quinine remained the mainstay of malaria treatment until the 1920s, when more effective synthetic anti-malarials became available. The most important of these drugs was chloroquine, which was extensively used, especially beginning in the 1940s [6]. With heavy use, chloroquine resistance developed slowly. Resistance of Plasmodium falciparum to chloroquine was seen in parts of Southeast Asia and South America by the late 1950s, and was widespread in almost all areas with falciparum malaria by the 1980s. With increasing resistance to chloroquine, quinine again played a key role, particularly in the treatment of severe malaria [6]. To-date quinine continues to play a significant role in the management of malaria. This review, discusses the historical role of quinine, considers its current usage, and provides insight into the appropriate future use of quinine for the treatment of malaria. Information was obtained by searching published literature in the National Library of Medicine via Pub Med and MEDLINE search engines for research articles, reviews, books, and other reports. Identification of published reports was done using key word searches such as quinine and malaria treatment, quinine and drug resistance, quinine in pregnancy, quinine and antibiotic combinations, and quinine and HIV/TB infected populations.

\section{Quinine properties}

Quinine is a cinchona alkaloid that belongs to the aryl amino alcohol group of drugs. It is an extremely basic compound and is, therefore, always presented as a salt [6]. Various preparations exist, including the hydrochloride, dihydrochloride, sulphate, bisulphate, and gluconate salts; of these the dihydrochloride is the most widely used. Quinine has rapid schizonticidal action against intra-erythrocytic malaria parasites. It is also gametocytocidal for Plasmodium vivax and Plasmodium malariae, but not for Plasmodium falciparum. Quinine also has analgesic, but not antipyretic properties. The anti-malarial mechanism of action of quinine is unknown.

Quinine is rapidly absorbed both orally and parenterally, reaching peak concentrations within 1-3 hours[8]. It is distributed throughout the body fluids and is highly protein bound, mainly to alpha- 1 acid glycoprotein. The binding capacity in plasma is concentration dependent, but also depends on the levels of alpha-1 acid glycoprotein, which therefore makes comparisons between different studies difficult[9]. Quinine readily crosses the placental barrier and is also found in cerebral spinal fluid. Excretion is rapid - 80\% of the administered drug is eliminated by hepatic biotransformation and the remaining $20 \%$ is excreted unchanged by the kidney [10-12]. The half-life of quinine ranges between 11-18 hours $[13,14]$. Several pharmacokinetic characteristics of quinine differ according to the age of the subject and are also affected by malaria. The volume of distribution is less in young children than in adults, and the rate of elimination is slower in the elderly than in young adults. In patients with acute malaria the volume of distribution is reduced and systemic clearance is slower than in healthy subjects; these changes are proportional to the severity of the disease. As a result, plasma quinine levels are higher in patients with malaria. Protein binding of quinine is increased in patients with malaria as a result of an increased circulating concentration of alpha-1 acid glycoprotein [15].

Quinine has a low therapeutic index, and adverse effects with its use are substantial [16]. The side effects commonly seen at therapeutic concentrations are referred to as cinchonism, with mild forms including tinnitus, slight impairment of hearing, headache and nausea. Impairment of hearing is usually concentration dependent and reversible [17]. More severe manifestations include vertigo, vomiting, abdominal pain, diarrhea, marked auditory loss, and visual symptoms, including loss of vision. Hypotension may occur if the drug is given too rapidly, and venous thrombosis may occur following intravenous injections [10]. Intramuscular administration is painful and may cause sterile abscesses. Hypoglycaemia is yet another common side effect of quinine therapy $[15,18]$ and is a particular problem in pregnant women[19]. Hypoglycaemia has been reported to occur in up to $32 \%$ of patients receiving quinine therapy[18]. However in more recent studies, hypoglycaemia occurred in only $3 \%$ of adults and $2.8 \%$ of African children receiving quinine [20,21]. Less frequent but more serious side effects of quinine therapy include skin eruptions, asthma, thrombocytopaenia, hepatic injury and psychosis [22].

\section{Overview of quinine use in the management of malaria}

Quinine remains an important anti-malarial drug, almost 400 years after Jesuit priests first documented its effectiveness. The 2010 World Health Organisation (WHO) guidelines recommend a combination of quinine plus doxycycline, tetracycline or clindamycin as secondline treatment for uncomplicated malaria (to be used when the first-line drug fails or is not available) and quinine plus clindamycin for treatment of malaria in the first trimester of pregnancy [23]. Based on recent trials, 
intravenous artesunate should be used for the treatment of severe falciparum malaria in adults [20] and children [21], in preference to quinine.

By 2009, 31 African countries recommended quinine as second-line treatment for uncomplicated malaria, 38 as first-line treatment of severe malaria and 32 for treatment of malaria in the first trimester of pregnancy [24]. In most of Africa, quinine is still used as monotherapy, contrary to the WHO recommendations[23,24]; the reason for this practice may be the higher costs of quinineantibiotic combinations. Quinine continues to play a significant role in the management of malaria in subSaharan Africa and other malaria endemic areas, and its use in routine practice may not be restricted to the stated WHO recommendations. In Cameroon, even one year after the introduction of ACT, quinine continued to be used as first-line therapy, with $45 \%$ of adults receiving oral quinine for uncomplicated malaria [25]. Recent surveillance data from sentinel sites in Uganda showed that quinine was prescribed for up to $90 \%$ of children $<5$ years with uncomplicated malaria [26].

The use of quinine for uncomplicated malaria cases should have decreased due to toxicities, poor compliance and the implementation of newer and better tolerated therapies such as ACT. However, the limited availability of ACT and the increasing resistance to chloroquine and antifolates have actually increased its use in recent times [27]. Therefore, studies evaluating the role of quinine in the management of malaria have been reviewed.

\section{Quinine for uncomplicated malaria}

In several settings, oral quinine continues to be used as treatment for uncomplicated malaria, a practice mainly resulting from frequent stock-outs of the recommended ACT [26,28]. Previous studies of the effectiveness and efficacy of quinine for uncomplicated malaria showed mixed results (Table 1 ). The majority of these studies were conducted in settings with reported declining efficacy of quinine in Southeast Asia and South America. Earlier studies in these regions, using varying dosing regimens, showed cure rates ranging from $76 \%$ to $98 \%$. The lower cure rates were mainly observed with shorter regimens (3 days) and higher cure rates when the drug was combined with sulphadoxine-pyrimethamine, tetracycline or clindamycin [29-34]. Similar findings were reported in Vietnam, where a three-day course of quinine plus artesunate had a cure rate of only $50 \%$, compared to a fiveday course, which had a cure rate of $76 \%$ [35]. Studies in Southeast Asia using quinine monotherapy for 7 days showed cure rates of $85-87 \%$ [29,33], which is similar to what was observed over 15 years earlier [36], (Table 1).

Moreover, the addition of either tetracycline or clindamycin to quinine in the Thai study improved cure rates to $98 \%$ and $100 \%$ respectively and also delayed the appearance of Plasmodium vivax infection, suggesting additional activity against this species [33].

In Africa, studies evaluating three-day quinine treatment regimens have usually found unacceptably high failure rates [37], with recurrent infections at day 28 post-treatment experienced in $30 \%-50 \%$ of patients [37-39]. However most of these studies did not perform PCR analyses to distinguish between recrudescence and re-infection, leading to possible underestimation of efficacy. In interpreting these results, the malaria transmission intensity at the study sites needs to be taken into consideration, as high treatment failure rates in high transmission settings may be due to a high risk of new infections. Additional PCR unadjusted studies that have evaluated five-day regimens of quinine have found recurrent infection rates on day 7 between $4 \%$ and $7 \%$ [40] and day 14 treatment failure rates of 0 to $5 \%$ (Table 1) [41,42]. In Equatorial Guinea, five-day courses of quinine were associated with day 14 PCR unadjusted failure rates as high as $22 \%$. These latter results prompted a change in the quinine treatment regimen for this region to a 7 day course, with subsequent significant decrease in treatment failure rates to $3 \%-5.5 \%$ [43]. This study also reported that treatment failure rates with quinine remained stable over the five-year period of surveillance.

Even with seven-day treatment durations, evaluations of different quinine dosage regimens have revealed interesting trends. Doses of $10 \mathrm{mg} / \mathrm{kg} /$ day given twice daily for 7 days were associated with day 28 treatment failure rates as high as $30 \%$ [37]. Increasing the quinine dosage to $15 \mathrm{mg} / \mathrm{kg} /$ day or $20 \mathrm{mg} / \mathrm{kg} /$ day improved treatment outcomes, with failure rates ranging from $8 \%$ to $14 \%$ [37], although potential increases in toxicity with higher dosages are a concern. The treatment regimen currently recommended in sub-Saharan Africa is $10 \mathrm{mg} /$ $\mathrm{kg}$ of the base given 8 hourly for 7 days. This regimen was associated with a lower rate of recurrent infections on day $28(6.3 \%)$ compared to the $10 \mathrm{mg} / \mathrm{kg}$ twice daily regimen (16.1\%)[44].

The advent of ACT has provided important new therapeutic options for the management of uncomplicated malaria in regions with high prevalence of multi-drug resistant malaria. A few available trials have shown superiority of ACT over quinine in the management of uncomplicated malaria $[32,45,46]$. In Brazil, patients treated with artemether-lumefantrine $(A L)$ had significantly faster parasite clearance times when compared to those treated with quinine+doxycycline [46]. Considering the extensive available data, quinine should not be used to treat uncomplicated malaria when ACT is available $[27,45]$. ACT has the advantages of simplicity of dosing, which promotes adherence to therapy when 
Table 1 Summary of studies of quinine for the treatment of uncomplicated malaria

\begin{tabular}{|c|c|c|c|c|c|c|c|}
\hline Study site & Year & $\begin{array}{c}\text { Sample size } \\
\text { and study } \\
\text { population }\end{array}$ & Drug Regimens & $\begin{array}{l}\text { Duration } \\
\text { of follow- } \\
\text { up }\end{array}$ & $\begin{array}{l}\text { Treatment } \\
\text { outcome }\end{array}$ & Comment & Reference \\
\hline $\begin{array}{l}\text { Thailand, region with } \\
\text { multidrug resistant } \\
\text { malaria }\end{array}$ & $\begin{array}{l}1984- \\
1985\end{array}$ & $\begin{array}{l}66 \text { children } \\
2-12 \text { years }\end{array}$ & $\begin{array}{l}\text { Quinine } \\
\text { Quinidine }\end{array}$ & $\begin{array}{l}28 \text { days } \\
\text { DOT }\end{array}$ & $\begin{array}{l}\text { Cure rates: } \\
\text { Quinine - } \\
85 \% \\
\text { Quinidine - } \\
88 \%\end{array}$ & $\begin{array}{l}\text { Treatment failures only Rl } \\
\text { responses }\end{array}$ & {$[29]$} \\
\hline $\begin{array}{l}\text { Cambodia, region with } \\
\text { multidrug resistant } \\
\text { malaria }\end{array}$ & 1983 & $\begin{array}{l}119 \text { adults, } \\
>15 \text { years }\end{array}$ & $\begin{array}{l}\text { Mefloquine +SP } \\
\text { (MSP) } \\
3 \text { days quinine } \\
\text { +tetracycline } \\
\text { (Q3T7) } \\
7 \text { days of quinine } \\
\text { + tetracycline } \\
\text { (Q7T7) }\end{array}$ & $\begin{array}{l}28 \text { days } \\
\text { DOT }\end{array}$ & $\begin{array}{l}\text { Cure rates: } \\
\text { MSP: } 98 \% \\
\text { Q3T7: } 76 \% \\
\text { Q7T7: } 92 \%\end{array}$ & Q7T7 still gives good cure rate & {$[30]$} \\
\hline $\begin{array}{l}\text { Brazil, setting with } \\
\text { quinine resistance }\end{array}$ & 1985 & $\begin{array}{l}100 \text { patients } \\
18-55 \text { years }\end{array}$ & $\begin{array}{l}\text { Mefloquine } 1000 \\
\text { mg single dose } \\
\text { (MQ) } \\
3 \text { days quinine } \\
+ \text { SP (Q3+SP) }\end{array}$ & $\begin{array}{l}42 \text { days } \\
\text { DOT }\end{array}$ & $\begin{array}{l}\text { Cure rates: } \\
\text { MQ: } \\
96 \% \\
\text { Q3 + SP: 98\% }\end{array}$ & $\begin{array}{l}\text { Four } \mathrm{Rl} \text { responses in } \mathrm{Q} 3+\mathrm{SP} \\
\text { group }\end{array}$ & {$[31]$} \\
\hline $\begin{array}{l}\text { Thailand, region with } \\
\text { multidrug resistant } \\
\text { malaria }\end{array}$ & 1994 & $\begin{array}{l}102 \text { patients } \\
16-60 \text { years }\end{array}$ & $\begin{array}{l}\text { Mefloquine } \\
\text { +tetracycline } \\
\text { (MQT) } \\
7 \text { days of Quinine } \\
+ \text { tetracycline } \\
\text { (Q7T7) }\end{array}$ & $\begin{array}{l}28 \text { days } \\
\text { DOT }\end{array}$ & $\begin{array}{l}\text { Cure rates: } \\
\text { MQT: } 94 \% \\
\text { Q7T7: } 98 \%\end{array}$ & MQ + Tetra as effective as Q7T7 & [34] \\
\hline $\begin{array}{l}\text { Thailand, region with } \\
\text { multidrug resistant } \\
\text { malaria }\end{array}$ & $\begin{array}{l}1995- \\
1997\end{array}$ & $\begin{array}{l}204 \text { male } \\
\text { patients } \\
15-64 \text { years }\end{array}$ & $\begin{array}{l}7 \text { days quinine } \\
\text { (Q7) } \\
\text { Quinine + } \\
\text { tetracycline } \\
\text { (Q7T7) } \\
\text { Quinine }+ \\
\text { clindamycin } \\
\text { (Q7C7) }\end{array}$ & $\begin{array}{l}28 \text { days } \\
\text { Directly } \\
\text { observed } \\
\text { therapy }\end{array}$ & $\begin{array}{l}\text { Cure rates: } \\
\text { Q7: } 87 \% \\
\text { Q7T7: } 98 \% \\
\text { Q7C7: } 100 \%\end{array}$ & $\begin{array}{l}\text { Tetracycline or clindamycin } \\
\text { improves quinine cure rates }\end{array}$ & {$[33]$} \\
\hline $\begin{array}{l}\text { Equatorial Guinea, } \\
\text { setting with no quinine } \\
\text { resistance }\end{array}$ & 1999 & $\begin{array}{l}114 \text { children } \\
6-59 \text { months }\end{array}$ & $\begin{array}{l}\text { 7days quinine } \\
\text { (Q7) } \\
\text { Chloroquine (CQ) } \\
\text { Sulfadoxine/ } \\
\text { pyrimethamine } \\
\text { (SP) }\end{array}$ & $\begin{array}{l}114 \text { day } \\
\text { follow-up }\end{array}$ & $\begin{array}{l}\text { Cure rates: } \\
\text { Q7: } 94.5 \% \\
\text { CQ: } 60 \% \\
\text { SP: } 90 \%\end{array}$ & $\begin{array}{l}\text { Quinine is effective against } P \text {. } \\
\text { falciparum malaria }\end{array}$ & [43] \\
\hline $\begin{array}{l}\text { Cameroon, High } \\
\text { transmission setting }\end{array}$ & 2005 & $\begin{array}{l}30 \text { children } \\
0.5-6 \text { years }\end{array}$ & $\begin{array}{l}5 \text { days quinine } \\
\text { (Q5) }\end{array}$ & $\begin{array}{l}14 \text { day } \\
\text { follow-up }\end{array}$ & $\begin{array}{l}\text { Cure rates: } \\
100 \%\end{array}$ & & [41] \\
\hline $\begin{array}{l}\text { Burundi Perennial } \\
\text { transmission setting }\end{array}$ & $\begin{array}{l}1992- \\
1995\end{array}$ & $\begin{array}{l}472 \text { children } \\
0-14 \text { years }\end{array}$ & $\begin{array}{l}\text { Chloroquine (CQ) } \\
5 \text { days quinine } \\
\text { (Q5) }\end{array}$ & $\begin{array}{l}7 \text { day } \\
\text { follow-up }\end{array}$ & $\begin{array}{l}\text { Failure rates } \\
\text { Q5: } \\
\text { 1992-1993: } \\
\text { 4.2\% } \\
1994-1995: \\
7.1 \% \\
\end{array}$ & & {$[40]$} \\
\hline $\begin{array}{l}\text { Guinea-Bissau Perennial } \\
\text { transmission setting }\end{array}$ & $\begin{array}{l}1994- \\
1995\end{array}$ & $\begin{array}{l}203 \text { children } \\
0.7-13 \text { years }\end{array}$ & $\begin{array}{l}3 \text { days quinine } \\
\text { (Q3) } \\
5 \text { days quinine } \\
\text { (Q5) } \\
7 \text { days quinine } \\
\text { (Q7) }\end{array}$ & $\begin{array}{l}28-35 \text { day } \\
\text { follow-up }\end{array}$ & $\begin{array}{l}\text { Day } 28 \\
\text { recurrent } \\
\text { parasitemia: } \\
\text { Q3: } 79 \% \\
\text { Q5: } 90 \% \\
\text { Q7: } 11 \% \\
\end{array}$ & $\begin{array}{l}3 \text { day quinine regimens should } \\
\text { not be used. }\end{array}$ & {$[37]$} \\
\hline $\begin{array}{l}\text { Gabon High } \\
\text { transmission setting }\end{array}$ & $\begin{array}{l}1993- \\
1994\end{array}$ & $\begin{array}{c}120 \text { adults = } \\
15 \text { years }\end{array}$ & $\begin{array}{l}3 \text { days quinine } \\
\text { (Q3) } \\
3 \text { days quinine } \\
\text { +clindamycin } \\
\text { (Q3C3) } \\
3 \text { days quinine } \\
\text { +doxycycline } \\
\text { (Q3D3) }\end{array}$ & $\begin{array}{l}28 \text { day } \\
\text { follow-up }\end{array}$ & $\begin{array}{l}\text { Day } 28 \text { cure } \\
\text { rates: } \\
\text { Q3: } 38 \% \\
\text { Q3C3: } 92 \% \\
\text { Q3D3: } 91 \%\end{array}$ & $\begin{array}{l}\text { The two short course } \\
\text { combinations of quinine had } \\
\text { excellent cure rates }\end{array}$ & [109] \\
\hline $\begin{array}{l}\text { Uganda Meso-endemic } \\
\text { transmission setting }\end{array}$ & $\begin{array}{l}2007- \\
2008\end{array}$ & $\begin{array}{l}175 \text { children } \\
6 \text { months - } 5 \\
\text { years }\end{array}$ & $\begin{array}{l}7 \text { days quinine } \\
\text { (Q7) } \\
3 \text { days } \\
\text { artemether- } \\
\text { lumefantrine }(\mathrm{AL})\end{array}$ & $\begin{array}{l}28 \text { day } \\
\text { follow-up }\end{array}$ & $\begin{array}{l}\text { Cure rates: } \\
\text { Q7: } 64 \% \\
\text { AL: } 97 \%\end{array}$ & $\begin{array}{l}\text { Results question the advisability of } \\
\text { quinine use for uncomplicated } \\
\text { malaria }\end{array}$ & {$[45]$} \\
\hline
\end{tabular}


compared with the seven-day treatment courses of quinine $[32,45]$, better tolerance and decreased risks of serious toxicity.

Nevertheless, despite their scale up in Africa, the cost and availability of ACT in the public sector remains a major challenge. In 2008, ACT coverage in the public sector in high-burden African countries was only $42 \%$ [47]. Similarly, a survey carried out during the same year in seven African countries showed that the percentage of fever cases in children $<5$ years treated with ACT was only $16 \%$ [47]. The sustainability of ACT supplies in resource limited settings therefore presents a huge problem, with stock-outs consistently occurring in health facilities [48]. Quinine, on the other hand, is a relatively cheap drug and often the only available option, rendering its rapid withdrawal for uncomplicated malaria cases risky. The best approach in these settings would be to proactively identify solutions to ACT stockouts and maintain quinine as a fall-back drug only in case of ACT stock-outs. Additionally, improving quinine treatment outcomes by combining it with antibiotics, such as tetracycline or clindamycin [49-51], could be investigated and promoted. More recently, combinations of quinine and newer antibiotics with shorter treatment regimens that would improve adherence to therapy as well as minimize related adverse events have been evaluated. One such combination is that with azithromycin which is of particular interest, as the drugs act synergistically [52]. This combination offers promise for use especially in pregnant women and children $<8$ years, since, unlike tetracyclines, both drugs are safe in these groups. A study in Thailand showed comparable efficacy in the treatment of multidrug resistant malaria, with cure rates of $100 \%$, for a seven-day course of quinine + doxycycline and a three-day course of quinine+azithromycin [49]. These drug combinations will need further evaluation to confirm these findings and may offer a solution to the compliance problems associated with seven-day courses of quinine.

\section{Quinine for malaria in pregnancy}

Malaria in pregnancy causes several adverse outcomes that include maternal anaemia, intrauterine growth retardation, low birth weight, preterm deliveries and abortion. Prevention and treatment of malaria in pregnancy is, therefore, critical to avoid these adverse outcomes. Currently the WHO recommends the use of quinine plus clindamycin for treating malaria in the first trimester of pregnancy, as the safety of artemisinin compounds during this period is not yet established [23]. As most clinical trials exclude women in their first trimester of pregnancy, information on the efficacy and safety of anti-malarial drugs during this period is extremely limited. Evidence for the safety of quinine in pregnancy is mostly historical and there are few clinical trials published $[50,53]$. Clindamycin on the other hand has a good safety record in pregnancy [54] and its pharmacokinetic properties are usually unchanged by pregnancy [55]. The combination of quinine and clindamycin has proven highly efficacious against multidrug-resistant strains of $P$. falciparum, with 42 day cure rates of $100 \%$ in one study [50]. The only concern with this combination is that it is usually not affordable for most resource limited settings. For the second and third trimester of pregnancy, quinine monotherapy seems to have unacceptably low efficacy in areas with multidrug resistant malaria when compared to ACT. Studies in these regions have shown that $\mathrm{ACT}$ performs better than oral quinine in terms of parasite clearance and fever clearance. Two studies in Thailand [56,57] reported fewer treatment failures at day 63 with artesunate plus atovaquone-proguanil and artesunate plus mefloquine, when compared with quinine. The occurrence of adverse events experienced by the pregnant women was similar in all groups, although tinnitus was more frequent in the quinine group. In these studies, the considerably inferior efficacy of quinine was attributed to both drug resistance and to the varying pharmacokinetic properties of quinine during pregnancy. In Africa however, available evidence suggests that Plasmodium. falciparum generally remains sensitive to quinine [58] and low cure rates with quinine monotherapy in pregnant women has been mainly attributed to poor compliance to treatment [59]. Thus in Africa, quinine monotherapy remains the most widely used treatment for malaria in the first trimester of pregnancy and is also considered safe during all trimesters of pregnancy. A recent study from Uganda provides important reassurance of continued efficacy of quinine monotherapy in these regions of Africa. In this study, quinine and artemether-lumefantrine had similar efficacy for the treatment of uncomplicated malaria in the second and third trimesters of pregnancy [60]. The evidence for safety of ACT use during the first trimester of pregnancy is currently limited [61]. Therefore, until more data become available, the recommendation to use quinine in the first trimester of pregnancy will remain and ACT should only be used in the second and third trimesters of pregnancy. Patient education and counseling will however be critical to promote compliance with therapy.

\section{Quinine in HIV or tuberculosis infected populations}

Interactions between HIV and malaria remain a major public health concern in areas affected by both diseases. Very few studies have evaluated the role of quinine in the management of malaria in HIV infected populations. The earliest study was done in the Congo in 1986 and it 
showed malaria cure rates of $92 \%$ in HIV infected patients treated with oral quinine with comparable results in HIV-negative patients [62]. In a subsequent study in the same region, no significant differences in treatment response were observed between children with progressive HIV infection and HIV-uninfected controls treated with oral quinine [63]. Such findings and other available data suggest that malaria treatment policy in HIV infected populations can generally follow the standard practices. Concerns however remain about potential interactions between anti-malarial and anti-retroviral drugs. Currently, there is little published information on the co-administration of antiretroviral therapy (ART) and anti-malarial drugs, yet this will become increasingly important with the rapid scale-up of ART in Africa. In Nigeria, concurrent administration of nevirapine and quinine led to significant reductions in the plasma levels of quinine and elevated plasma levels of 3-hydroxyquinine, the major metabolite of quinine [64]. This could potentially reduce the efficacy of quinine while increasing toxicity, since 3-hydroxyquinine has higher toxicity and lower anti-malarial activity than quinine. Interactions with ritonavir have also been described, with concurrent administration of these drugs leading to marked elevations in plasma levels of quinine and decreases in levels of 3-hydroxyquinine [65]. These results suggest the need for downward dosage adjustments of quinine with concurrent administration of ritonavir, including ritonavir-boosted protease inhibitor regimens.

The co-existence of tuberculosis (TB), malaria and HIV in sub-Saharan Africa and other settings causes additional concerns about their treatment. Interactions between rifampicin (a major component of first-line anti-TB treatment regimens) and quinine would be expected as rifampicin is a potent inducer of hepatic enzymes and quinine is metabolised mainly by the human CYP 3A isoenzyme. In vivo studies in healthy volunteers showed that when quinine was administered with rifampicin its mean clearance was significantly greater and mean elimination half-life shorter [66]. Interesting observations of the effect of combined quinine and rifampicin therapy were additionally reported in Thai patients with uncomplicated malaria [67]. In this study, parasite clearance times were shorter in the quinine-rifampicin group than in the group given quinine monotherapy, suggesting that the anti-malarial activity of rifampicin augmented that of quinine initially. However, recrudescence rates were five times higher in the quinine-rifampicin group than in the quinine-alone group[67]. These observations were explained by marked differences in the plasma quinine concentrations when rifampicin was combined with quinine. These results suggest that the quinine dosage might need to be increased in patients receiving rifampicin as an anti-TB drug.

Concerns also exist about potential interactions with the concurrent use of antiretroviral drugs and artemisinin-based combination therapy [68-70]. Further research and pharmacovigilance will be critical to facilitate the development of targeted treatment recommendations. Presently, it is not possible to elucidate advantages associated with the use of any particular anti-malarial drug for HIV or TB infected populations.

\section{Quinine in the management of severe malaria}

The treatment of severe malaria requires prompt, safe, and effective intravenous anti-malarial drugs. Over the years, quinine has been the mainstay in the treatment of severe malaria and still remains the first line drug in most African countries [24]. Though quinine dosing regimens have varied, the WHO recommends a dose of $20 \mathrm{mg} \mathrm{salt} / \mathrm{kg}$ by intravenous infusion, then $10 \mathrm{mg} / \mathrm{kg}$ every eight hours [23]. The rationale for the loading dose is the urgent need to achieve therapeutic plasma concentrations. One systematic review showed that a loading dose of quinine reduced fever and parasite clearance times, but there was insufficient data to demonstrate its impact on risk of death [71].

More recently, intravenous artesunate is the recommended treatment of choice for severe falciparum malaria in adults [23]. This recommendation was made on the basis of the dramatic results of the SEAQUAMAT trial conducted in Southeast Asia that showed a $35 \%$ reduction in the case-fatality rate in adults with severe malaria treated with intravenous artesunate compared to intravenous quinine[20]. Subsequent systematic reviews have also provided additional evidence for this recommendation [72]. However, about $80 \%$ of malaria deaths occur in sub-Saharan Africa among children aged $<5$ years. The therapeutic options previously recommended by WHO for the paediatric group included intravenous artesunate, intramuscular artemether or intravenous quinine[23]. Several trials and meta-analyses comparing intramuscular artemether with intravenous quinine have consistently shown no benefit of treatment with artemether over quinine in children with severe malaria in sub-Saharan Africa [73-75] (Table 2 ). The recently concluded AQUAMAT study now provides conclusive evidence of the superiority of intravenous artesunate over quinine in children $<15$ years, with a relative reduction of $23 \%$ in mortality associated with the use of artesunate[21]. These observations recently led to a change in WHO recommendations, with intravenous artesunate now advocated in preference to quinine for the management of severe malaria in children. The most critical issues that will need to be addressed, however, are the availability of intravenous artesunate 
for the patients who need it, especially in resource-limited settings, and its effectiveness in real-life settings. Until recently, the available formulations of injectable artesunate that have been used in several clinical trials were not produced according to Good Manufacturing Practices (GMP) and this could be a problem for African countries relying on donors who do not permit purchase of non-GMP artesunate. WHO recently prequalified intravenous artesunate manufactured by Guilin Pharmaceuticals in China and this may resolve problems of procurement of GMP artesunate. However, it is unclear whether supplies will be sufficient for the thousands of patients in need. Until these procurement and supplies issues are resolved, intravenous quinine may remain the only readily available drug for treating severe malaria in sub-Saharan Africa and other resource-limited settings. Furthermore, there are several health systems challenges related to the management of severe malaria in resource limited settings that impact on treatment outcomes, independent of the parenteral antimalarial drugs used. Consequently, changes in treatment policies, in this case from quinine to artesunate, may not offer improvements without considering drug availability as well as additional measures to strengthen health systems.

Another important aspect of severe malaria case management is pre-referral treatment, which is treatment given to a patient with severe malaria before they are referred to a health facility. This is critical, as most malaria deaths, especially in Africa, occur outside hospitals, either in the communities or at lower levels of care. Studies evaluating the role of rectal artesunate and artemether as pre-referral treatment have found these options to be highly efficacious [76,77]. However, the biggest challenge faced in resource limited settings has been the non-availability of these preparations in health facilities. A recent survey in Uganda found that rectal artemisinins were available in only $5 \%$ of the health facilities despite the fact that this is the recommended pre-referral drug [78]. A feasible alternative is rectal quinine, which has been found to have comparable efficacy with intravenous quinine in the management of severe malaria in children [79-84] (Table 2) and could play a more significant role than currently acknowledged as pre-referral treatment for severe malaria. More recent studies in Senegal and Mali provide additional support for the efficacy and feasibility of this route and also show that a pre-referral kit of rectal quinine was acceptable to both caretakers and health workers $[85,86]$.

Following successful administration of parenteral treatment for severe malaria, it is recommended to continue with an oral anti-malarial drug once a patient is able to tolerate oral therapy. The current practice is to continue the same medicine orally as given parenterally to complete a full treatment course [23]. The options for oral continuation therapy that are available in many African settings would therefore include oral quinine or an ACT. In non-pregnant adults, doxycyline would also be added to either of these drugs and given twice daily for 7 days. Where available, clindamycin may be substituted in children, since doxycyline is contraindicated in this age group [23]. The choice of oral continuation therapy following initial parenteral treatment of severe malaria may also have an impact on clinical outcomes, particularly on parasite clearance, fever clearance and potentially the risk of recurrent parasitaemia. In this regard completing intravenous quinine treatment with an ACT instead of oral quinine may improve the overall treatment outcome of parenteral quinine therapy. Studies evaluating this approach to therapy are limited. A study in Kenya during 2000-2002, showed that completing the intravenous quinine dose with oral malarone (atovaquone + proguanil) was associated with improved clinical outcomes compared to intravenous quinine followed by oral quinine [87] (Table 2). Additional studies should explore other options, in particular ACT, for improving therapeutic outcomes with intravenous quinine treatment.

\section{Potential explanations for quinine treatment failure}

\section{Quinine resistance}

Parasite drug resistance is probably the greatest problem faced by malaria control programs worldwide and is an important public health concern. Over the years, malaria parasites have developed resistance to a number of commonly used anti-malarial drugs. However the development of resistance to quinine has been slow. Although its use started in the $17^{\text {th }}$ century, resistance to quinine was first reported in 1910 [88]. In comparison, resistance to chloroquine and proguanil emerged within only 12 [89] and 1 year $[88,90]$ of their introduction, respectively. Resistance to quinine is usually low grade, with the drug retaining some activity but having its action delayed or diminished. Diminished sensitivity of P. falciparum to quinine has been widely documented in Asia [91] and South America [92] but it seems relatively uncommon in Africa where conflicting results of no resistance $[93,94]$ or varying degrees of resistance [95], [96] have been reported. A recent study from Thailand showed significant reductions in efficacy of quinine, artemisinin and mefloquine when compared to previous reports from the same area, suggesting further increase in drug resistance in this region [97]. No convincing evidence of high grade quinine resistance in the treatment of severe malaria has been reported. Findings from a recent systematic review of about 435 clinical trials published between 1966 and 2002 showed that the 
Table 2 Summary of studies of quinine for the treatment of severe malaria

\begin{tabular}{|c|c|c|c|c|c|c|}
\hline Study site & Year & $\begin{array}{l}\text { Sample size and } \\
\text { Study } \\
\text { population }\end{array}$ & $\begin{array}{l}\text { Drug } \\
\text { Regimens }\end{array}$ & Treatment outcome & Comment & Reference \\
\hline Gambia & $\begin{array}{l}1992- \\
1994\end{array}$ & $\begin{array}{l}576 \text { children } \\
1-9 \text { years Cerebral } \\
\text { malaria }\end{array}$ & $\begin{array}{l}\text { Intramuscular } \\
\text { artemether } \\
\text { (IMA) } \\
\text { Intravenous } \\
\text { quinine (IVQ) }\end{array}$ & $\begin{array}{l}\text { Mortality: } \\
\text { IMA:20.5\% } \\
\text { IVQ: } 21.5 \% \\
\text { Neurological sequelae: } \\
\text { IMA: } 3.3 \% \\
\text { IVQ: } 5.3 \%\end{array}$ & $\begin{array}{l}\text { Artemether is as effective as quinine in treatment } \\
\text { of cerebral malaria in children }\end{array}$ & [74] \\
\hline Malawi & $\begin{array}{l}1992- \\
1994\end{array}$ & $\begin{array}{l}183 \text { children } \\
\text { Cerebral malaria }\end{array}$ & $\begin{array}{l}\text { Intramuscular } \\
\text { artemether } \\
\text { (IMA) } \\
\text { Intravenous } \\
\text { quinine (IVQ) }\end{array}$ & $\begin{array}{l}\text { Mortality: } \\
\text { IMA: } 11 \% \\
\text { IVQ: } 16 \% \\
\text { Survival with } \\
\text { neurological sequelae: } \\
\text { IMA: } 19 \% \\
\text { IVQ: } 12 \%\end{array}$ & $\begin{array}{l}\text { Results do not suggest artemether would confer a } \\
\text { survival advantage over quinine }\end{array}$ & [73] \\
\hline Kenya & $\begin{array}{l}2000- \\
2002\end{array}$ & $\begin{array}{l}360 \text { patients } \\
1-60 \text { years } \\
\text { Severe malaria }\end{array}$ & $\begin{array}{l}\text { IV Quinine + } \\
\text { oral malarone } \\
\text { (QM) } \\
\text { IV Quinine +oral } \\
\text { quinine (QQ) }\end{array}$ & $\begin{array}{l}\text { Day } 28 \text { cure rates: } \\
\text { QM: } 98.7 \% \\
\text { QQ: } 90 \%\end{array}$ & $\begin{array}{l}\text { Using malarone after IV quinine is safer and as } \\
\text { effective as IV quinine +oral quinine }\end{array}$ & {$[87]$} \\
\hline $\begin{array}{l}\text { Burkina } \\
\text { Faso }\end{array}$ & $\begin{array}{l}2001- \\
2002\end{array}$ & $\begin{array}{l}898 \text { children } \\
1-15 \text { years } \\
\text { Moderately severe } \\
\text { malaria }\end{array}$ & $\begin{array}{l}\text { Rectal quinine } \\
\text { (RQ) } \\
\text { Intramuscular } \\
\text { quinine (IMQ) }\end{array}$ & $\begin{array}{l}\text { Early treatment failure } \\
\text { (day 3): } \\
\text { RQ: 6\% } \\
\text { IMQ: } 3 \% \\
\text { Fever recurrence on day } \\
7: \\
\text { RQ: } 5 \% \\
\text { IMQ: } 10 \%\end{array}$ & $\begin{array}{l}\text { Rectal quinine had acceptable safety profile and } \\
\text { could be used as early treatment for severe } \\
\text { malaria }\end{array}$ & {$[84]$} \\
\hline Uganda & $\begin{array}{l}2002- \\
2003\end{array}$ & $\begin{array}{l}103 \text { children } \\
0.5-5 \text { years } \\
\text { Cerebral malaria }\end{array}$ & $\begin{array}{l}\text { Rectal } \\
\text { artemether (RA) } \\
\text { Intravenous } \\
\text { quinine (IVQ) }\end{array}$ & $\begin{array}{l}\text { Mortality: } \\
\text { IVQ: } 11.7 \% \\
\text { RA: } 19.2 \%\end{array}$ & Rectal artemether was effective and well tolerated & [76] \\
\hline $\begin{array}{l}\text { S.E Asia } \\
\text { (Four } \\
\text { countries) }\end{array}$ & $\begin{array}{l}2003- \\
2005\end{array}$ & $\begin{array}{l}1461 \text { patients } \\
>2 \text { years } \\
\text { Severe malaria }\end{array}$ & $\begin{array}{l}\text { Intravenous } \\
\text { artesunate (IVA) } \\
\text { Intravenous } \\
\text { quinine (IVQ) }\end{array}$ & $\begin{array}{l}\text { Mortality: } \\
\text { IVA: } 15 \% \\
\text { IVQ: } 22 \% \\
\text { Absolute reduction in } \\
\text { mortality: } 34.7 \%\end{array}$ & $\begin{array}{l}\text { Intravenous artesunate should be treatment of } \\
\text { choice for severe malaria in adults }\end{array}$ & {$[20]$} \\
\hline Uganda & $\begin{array}{l}2003- \\
2004\end{array}$ & $\begin{array}{l}110 \text { children } \\
0.5-5 \text { years } \\
\text { Cerebral malaria }\end{array}$ & $\begin{array}{l}\text { Rectal quinine } \\
\text { (RQ) } \\
\text { Intravenous } \\
\text { quinine (IVQ) }\end{array}$ & $\begin{array}{l}\text { Mortality: } \\
\text { RQ: } 7 \% \\
\text { IVQ: } 9 \% \\
\text { Comparable clinical and } \\
\text { parasitological outcomes }\end{array}$ & $\begin{array}{l}\text { Rectal quinine was efficacious and could be used } \\
\text { as a treatment alternative }\end{array}$ & [79] \\
\hline $\begin{array}{l}\text { Africa (Nine } \\
\text { countries) }\end{array}$ & $\begin{array}{l}2005- \\
2010\end{array}$ & $\begin{array}{l}5425 \text { children } \\
<15 \text { years Severe } \\
\text { malaria }\end{array}$ & $\begin{array}{l}\text { Intravenous } \\
\text { artesunate (IVA) } \\
\text { Intravenous } \\
\text { quinine (IVQ) }\end{array}$ & $\begin{array}{l}\text { Mortality: } \\
\text { IVA: } 8.5 \% \\
\text { IVQ: } 10.9 \% \\
\text { Relative reduction in } \\
\text { mortality: } 22.5 \%\end{array}$ & $\begin{array}{l}\text { Parenteral artesunate should replace quinine as } \\
\text { the treatment of choice for severe malaria }\end{array}$ & {$[21]$} \\
\hline
\end{tabular}

recrudescence rates for quinine reported over these past 30 years remained roughly constant [98]. These findings are encouraging and may suggest that efficacy of quinine has been preserved.

\section{Variations in quinine pharmacokinetics}

Treatment failures with quinine could also be explained by varying pharmacokinetic profiles of the drug. It is known that quinine pharmacokinetic properties and therapeutic responses vary with age, pregnancy, immunity and disease severity [99]. Also, as patients recover from malaria, there is usually an expansion of the volume of distribution and an increase in systemic clearance of quinine resulting in a decline in the average concentration of quinine in plasma [100]. These variations may lead to drug levels that may be inadequate to completely clear infection. The possibility that pharmacokinetic factors may explain quinine treatment failure was initially raised about 20 years ago when a Thai patient who had fatal severe malaria and apparent RIII resistance was found to have abnormally low levels of quinine despite adequate dosing [101]. Additional evidence for the impact of unusual quinine pharmacokinetics on treatment outcomes was provided by a more 
recent study describing early treatment failure in a patient with severe malaria with an abnormally high volume of distribution and increased quinine clearance, resulting in abnormally low quinine concentrations [102]. A few studies have proposed that an increase in the quinine dosage after the third day could compensate for declines in plasma drug levels during recovery, especially in areas with resistant P. falciparum [99]. However, this is not routinely practiced. Despite these anecdotal observations, there is little evidence for large variations in quinine pharmacokinetics [103] and the exact role that variations in drug levels play in quinine treatment responses is unclear.

\section{Quinine drug quality and treatment compliance}

The quality of quinine used in routine care could play a key role in clinical outcomes. Poor quality drugs remain a problem worldwide and are a serious public health threat. A study in Nigeria evaluating the quality of different anti-malarial drugs found that $37 \%$ of 225 antimalarial drugs did not meet the tolerance limits set by United Sates Pharmacopeia (USP) for the amount of active ingredient, and $46 \%$ of these were formulations of quinine [104]. In Congo, Burundi and Angola only 89\% of the declared active substance was found in quinine tablets, with high quantities of impurities reported [105]. Another worrying situation was unveiled in a survey in Cameroon, where nearly $74 \%$ of 70 quinine samples had no active ingredient [106]. Several other studies have also described varying problems with quinine drug quality in different settings $[107,108]$. Ideally, branded antimalarial drugs should be used, but unfortunately, branded quinine products are not universally available in Africa and other malaria endemic settings. In addition, national drug regulators need to strengthen their roles in the monitoring of anti-malarial drug quality.

Another potential explanation for quinine treatment failures may be poor compliance. Quinine's prolonged treatment course and significant tolerability problems may lead to poor compliance, and hence poor therapeutic outcomes $[32,45,59]$. In this aspect, ACT has an advantage over quinine since it is administered once or twice daily over three days. A recent study in Uganda showed comparable compliance on day 3 of treatment in patients taking either quinine or artemether-lumefantrine. However, non-compliance to quinine greatly increased with increasing days on therapy to about $44 \%$ by day 7 [45]. Promotion of shorter courses of quinine, especially in combination with antibiotics, should improve compliance as well as treatment outcomes [39,109].

\section{Conclusion}

In the near future, quinine will continue to play a significant role in the management of malaria, particularly in resource limited settings. Following the results of the SEAQUAMAT and AQUAMAT trials, artesunate is now recommended as the treatment of choice for severe malaria patients, with quinine only acting as an alternative when artesunate is not available. The role of rectal quinine as pre-referral treatment for severe malaria has not been fully explored, but this remains a promising intervention given the limited availability of rectal artemisinin preparations in resource limited settings. Quinine continues to play a critical role in the management of malaria in the first trimester of pregnancy, and will remain so until safer alternatives become available. The continued use of quinine in the management of uncomplicated malaria is a concern. Clearly, the seven day duration of therapy and thrice daily administration of quinine present a major challenge to completion of therapy, leading to sub-optimal treatment outcomes. In these situations, ACT is a better option given the simplicity of dosing and shorter treatment duration. However, because of the frequent ACT stock outs, the rapid withdrawal of quinine as a treatment option for uncomplicated malaria cases is risky. The best approach would be, besides improving the supply system, to maintain quinine as a fall-back drug in case of ACT stock-outs.

\section{Acknowledgements and funding}

We thank colleagues who have made useful comments on this manuscript. No funding was obtained for the preparation of this manuscript.

\section{Author details}

${ }^{1}$ Department of Pediatrics and Child Health, Makerere University College of Health Sciences, P.O. Box 7475, Kampala, Uganda. ${ }^{2}$ Department of Epidemiology and Biostatistics, Makerere University School of Public Health, P.O Box 7072, Kampala, Uganda. ${ }^{3}$ Department of Parasitology, Institute of Tropical Medicine, Nationalestraat 155, 2000 Antwerp, Belgium. ${ }^{4}$ Epidemiology Unit, Uganda Malaria Surveillance Project, P.O Box 7475, Kampala, Uganda. ${ }^{5}$ Communicable Diseases Control Department, Malaria Consortium Africa, P.O Box 8045, Kampala, Uganda. ${ }^{6}$ Department of Medicine, University of California San Francisco, 1001 Potrero Ave, SFGH 30, San Francisco, CA, 94143, USA.

\section{Authors' contributions}

AJ, PJR and UD conceived the idea and wrote the first draft of the manuscript. All authors read and approved the final version

\section{Competing interests}

The authors declare that they have no competing interests.

Received: 31 January 2011 Accepted: 24 May 2011

Published: 24 May 2011

\section{References}

1. How Was Quinine Discovered?. [http://www.ehow.com/ facts 5828007_quinine-discovered_html\#ixzz1JrTqGgQq]. David B, Jacoby RMY: Encyclopedia of Family Health., Third 2005 Quinine. [http://www.discoveriesinmedicine.com/Ni-Ra/Quinine.html]. Cinchona bark. [http://historyofmalaria.com/2010/02/cinchona-bark/]. Dobson SMaM: The history of antimalarial drugs. In Antimalarial Chemotherapy: Mechanisms of Action, Resistance, and New Directions in Drug Discovery. Edited by: PJ R. Totowa, New Jersey: Humana Press; 2001:15-25.

6. Yakoub AdenAbdi OE, Gustafsson LLars, Ericsson Orjan, Urban Hellgren: Handbook of Drugs for Tropical Parasitic Infections., 21995. 
7. BF H: Some notes on the Cinchona Industry. Chemical News 1931, 142:129-133

8. Salako LA, Sowunmi A: Disposition of quinine in plasma, red blood cells and saliva after oral and intravenous administration to healthy adult Africans. Eur J Clin Pharmacol 1992, 42(2):171-174.

9. Mihaly GW, Ching MS, Klejn MB, Paull J, Smallwood RA: Differences in the binding of quinine and quinidine to plasma proteins. $\mathrm{Br} J$ Clin Pharmacol 1987, 24(6):769-774.

10. White NJ: The treatment of malaria. N Engl J Med 1996, 335(11):800-806.

11. Tracy. WLaJ. e: Chemotherapy of parasitic infections. In Goodman and Gilman's Pharmacological basis of therapeutics Edited by: Alfred Goodman Gilman LEL JGH, 97:978-981.

12. Esamai F, Ayuo P, Owino-Ongor W, Rotich J, Ngindu A, Obala A, Ogaro F, Quoqiao L, Xingbo G, Guangqian L: Rectal dihydroartemisinin versus intravenous quinine in the treatment of severe malaria: a randomised clinical trial. East Afr Med J 2000, 77(5):273-278.

13. Jamaludin A, Mohamed M, Navaratnam V, Mohamed N, Yeoh E, Wernsdorfer $W$ : Single-dose comparative kinetics and bioavailability study of quinine hydrochloride, quinidine sulfate and quinidine bisulfate sustained-release in healthy male volunteers. Acta Leiden 1988, 57(1):39-46.

14. White NJ, Chanthavanich P, Krishna S, Bunch C, Silamut K: Quinine disposition kinetics. Br J Clin Pharmacol 1983, 16(4):399-403.

15. White NJ: Antimalarial pharmacokinetics and treatment regimens. $\mathrm{Br} J$ Clin Pharmacol 1992, 34(1):1-10.

16. WHO: Severe and complicated malaria. Trans R Soc Trop Med Hyg 2000, 94(Suppl 1):1-90.

17. Karlsson KK, Hellgren U, Alvan G, Rombo L: Audiometry as a possible indicator of quinine plasma concentration during treatment of malaria. Trans R Soc Trop Med Hyg 1990, 84(6):765-767.

18. Okitolonda W, Delacollette C, Malengreau M, Henquin JC: High incidence of hypoglycaemia in African patients treated with intravenous quinine for severe malaria. Br Med J (Clin Res Ed) 1987, 295(6600):716-718.

19. Looareesuwan S, Phillips RE, White NJ, Kietinun S, Karbwang J, Rackow C, Turner RC, Warrell DA: Quinine and severe falciparum malaria in late pregnancy. Lancet 1985, 2(8445):4-8.

20. Dondorp A, Nosten F, Stepniewska K, Day N, White N: Artesunate versus quinine for treatment of severe falciparum malaria: a randomised trial. Lancet 2005, 366(9487):717-725

21. Dondorp AM, Fanello Cl, Hendriksen IC, Gomes E, Seni A, Chhaganlal KD, Bojang K, Olaosebikan R, Anunobi N, Maitland K, Kivaya E, Agbenyega T, Nguah SB, Evans J, Gesase S, Kahabuka C, Mtove G, Nadjm B, Deen J, Mwanga-Amumpaire J, Nansumba M, Karema C, Umulisa N, Uwimana A, Mokuolu OA, Adedoyin OT, Johnson WB, Tshefu AK, Onyamboko MA, Sakulthaew T, Ngum WP, Silamut K, Stepniewska K, Woodrow CJ, Bethell D, Wills B, Oneko M, Peto TE, von Seidlein L, Day NP, White NJ, AQUAMAT group: Artesunate versus quinine in the treatment of severe falciparum malaria in African children (AQUAMAT): an open-label, randomised trial. Lancet 376(9753):1647-1657.

22. Antimalarial Martindale, The Extra Pharmacopoeia. London: Pharmaceuitical Press; 301993.

23. WHO: Malaria treatment guidelines. 2010

24. WHO: Global antimalarial drug policies database - WHO African region. 2009, September edn.

25. Sayang C, Gausseres M, Vernazza-Licht N, Malvy D, Bley D, Millet P: Treatment of malaria from monotherapy to artemisinin-based combination therapy by health professionals in rural health facilities in southern Cameroon. Malar J 2009, 8:174.

26. (UMSP) UMSP: UMSP sentinel site malaria surveillance report July 2010. 2010.

27. Yeka A, Achan J, D'Alessandro U, Talisuna AO: Quinine monotherapy for treating uncomplicated malaria in the era of artemisinin-based combination therapy: an appropriate public health policy? Lancet Infect Dis 2009, 9(7):448-452.

28. Wasunna B, Zurovac D, Goodman CA, Snow RW: Why don't health workers prescribe ACT? A qualitative study of factors affecting the prescription of artemether-lumefantrine. Malar J 2008, 7:29

29. Sabchareon A, Chongsuphajaisiddhi T, Sinhasivanon V, Chanthavanich $P$, Attanath $P$ : In vivo and in vitro responses to quinine and quinidine of Plasmodium falciparum. Bull World Health Organ 1988, 66(3):347-352.
30. Meek SR, Doberstyn EB, Gauzere BA, Thanapanich C, Nordlander E, Phuphaisan S: Treatment of falciparum malaria with quinne and tetracycline or combined mefloquine/sulfadoxine/pyrimethamine on the Thai-Kampuchean border. Am J Trop Med Hyg 1986, 35(2):246-250.

31. de Souza JM, Sheth UK, de Oliveira RM, Roulet H, de Souza SD: An open, randomized, phase III clinical trial of mefloquine and of quinine plus sulfadoxine-pyrimethamine in the treatment of symptomatic falciparum malaria in Brazil. Bull World Health Organ 1985, 63(3):603-609.

32. Fungladda W, Honrado ER, Thimasarn K, Kitayaporn D, Karbwang J, Kamolratanakul P, Masngammueng R: Compliance with artesunate and quinine + tetracycline treatment of uncomplicated falciparum malaria in Thailand. Bull World Health Organ 1998, 76(Suppl 1):59-66.

33. Pukrittayakamee S, Chantra A, Vanijanonta S, Clemens R, Looareesuwan S, White $\mathrm{NJ}$ : Therapeutic responses to quinine and clindamycin in multidrug-resistant falciparum malaria. Antimicrob Agents Chemother 2000, 44(9):2395-2398

34. Looareesuwan S, Vanijanonta S, Viravan C, Wilairatana P, Charoenlarp P, Lasserre R, Canfield C, Kyle DE, Webster HK: Randomised trial of mefloquine-tetracycline and quinine-tetracycline for acute uncomplicated falciparum malaria. Acta Trop 1994, 57(1):47-53.

35. de Vries PJBN, Van Thien H, Hung LN, Anh TK, Kager PA, Heisterkamp SH: Combinations of artemisinin and quinine for uncomplicated falciparum malaria: efficacy and pharmacodynamics. Antimicrob Agents Chemother 2000, 44(5):1302-1308.

36. Harinasuta TBD: Drug resistant malaria with special reference to chemotherapy. Mosquito-Borne Diseases Bulletin 1984, 1(23-30).

37. Kofoed PE, Mapaba E, Lopes F, Pussick F, Aaby P, Rombo L: Comparison of 3, 5 and 7 days' treatment with Quinimax for falciparum malaria in Guinea-Bissau. Trans R Soc Trop Med Hyg 1997, 91(4):462-464.

38. Rogier C, Brau R, Tall A, Cisse B, Trape JF: Reducing the oral quininequinidine-cinchonin (Quinimax) treatment of uncomplicated malaria to three days does not increase the recurrence of attacks among children living in a highly endemic area of Senegal. Trans $R$ Soc Trop Med Hyg 1996, 90(2):175-178.

39. Kremsner PG, Winkler S, Brandts C, Neifer S, Bienzle U, Graninger W: Clindamycin in combination with chloroquine or quinine is an effective therapy for uncomplicated Plasmodium falciparum malaria in children from Gabon. J Infect Dis 1994, 169(2):467-470.

40. Di Perri GOP, Nardi S, Deganello R, Allegranzi B, Bonora S, Vento S, Concia E: Response of uncomplicated falciparum malaria to oral chloroquine and quinine in Burundi highlands. Acta Trop 1998, 70(1):25-33.

41. Le Jouan MJV, Tetanye E, Tran A, Rey E, Treluyer JM, Tod M, Pons G: Quinine pharmacokinetics and pharmacodynamics in children with malaria caused by Plasmodium falciparum. Antimicrob Agents Chemother 2005, 49(9):3658-3662.

42. Roche J, Benito A, Ayecaba S, Amela C, Molina R, Alvar J: Resistance of Plasmodium falciparum to antimalarial drugs in Equatorial Guinea. Ann Trop Med Parasitol 1993, 87(5):443-449.

43. Roche J, Guerra-Neira A, Raso J, Benito A: Surveillance of in vivo resistance of Plasmodium falciparum to antimalarial drugs from 1992 to 1999 in Malabo (Equatorial Guinea). Am J Trop Med Hyg 2003, 68(5):598-601.

44. Ibrahim MH, Elbashir MI, Naser A, Aelbasit IA, Kheir MM, Adam I: Low-dose quinine is effective in the treatment of chloroquine-resistant Plasmodium falciparum malaria in eastern Sudan. Ann Trop Med Parasitol 2004, 98(5):441-445.

45. Achan J, Tibenderana JK, Kyabayinze D, Wabwire Mangen F, Kamya MR, Dorsey G, D'Alessandro U, Rosenthal PJ, Talisuna AO: Effectiveness of quinine versus artemether-lumefantrine for treating uncomplicated falciparum malaria in Ugandan children: randomised trial. BMJ 2009, 339: b2763.

46. Alecrim MG, Lacerda MV, Mourao MP, Alecrim WD, Padilha A, Cardoso BS, Boulos M: Successful treatment of Plasmodium falciparum malaria with a six-dose regimen of artemether-lumefantrine versus quinine-doxycycline in the Western Amazon region of Brazil. Am J Trop Med Hyg 2006, 74(1):20-25.

47. WHO: World Malaria Report 2009. 2009.

48. Kangwana BB, Njogu J, Wasunna B, Kedenge SV, Memusi DN, Goodman CA, Zurovac D, Snow RW: Malaria drug shortages in Kenya: a major failure to provide access to effective treatment. Am J Trop Med Hyg 2009, 80(5):737-738. 
49. Miller RS, Wongsrichanalai C, Buathong N, McDaniel P, Walsh DS, Knirsch C, Ohrt C: Effective treatment of uncomplicated Plasmodium falciparum malaria with azithromycin-quinine combinations: a randomized, doseranging study. Am J Trop Med Hyg 2006, 74(3):401-406.

50. McGready R, Cho T, Samuel, Villegas L, Brockman A, van Vugt M, Looareesuwan S, White NJ, Nosten F: Randomized comparison of quinineclindamycin versus artesunate in the treatment of falciparum malaria in pregnancy. Trans R Soc Trop Med Hyg 2001, 95(6):651-656.

51. Parola P, Ranque S, Badiaga S, Niang M, Blin O, Charbit JJ, Delmont J, Brouqui P: Controlled trial of 3-day quinine-clindamycin treatment versus 7-day quinine treatment for adult travelers with uncomplicated falciparum malaria imported from the tropics. Antimicrob Agents Chemother 2001, 45(3):932-935.

52. Noedl H, Krudsood S, Chalermratana K, Silachamroon U, Leowattana W, Tangpukdee N, Looareesuwan S, Miller RS, Fukuda M, Jongsakul K, Sriwichai S, Rowan J, Bhattacharyya H, Ohrt C, Knirsch C: Azithromycin combination therapy with artesunate or quinine for the treatment of uncomplicated Plasmodium falciparum malaria in adults: a randomized, phase 2 clinical trial in Thailand. Clin Infect Dis 2006, 43(10):1264-1271.

53. Adam I, Ibrahim MH, Ae IA, Elbashir MI: Low-dose quinine for treatment of chloroquine-resistant falciparum malaria in Sudanese pregnant women. East Mediterr Health J 2004, 10(4-5):554-559.

54. Lell B, Kremsner PG: Clindamycin as an antimalarial drug: review of clinical trials. Antimicrob Agents Chemother 2002, 46(8):2315-2320.

55. Philipson A, Sabath LD, Charles D: Erythromycin and clindamycin absorption and elimination in pregnant women. Clin Pharmacol Ther 1976, 19(1):68-77.

56. McGready R, Ashley EA, Moo E, Cho T, Barends M, Hutagalung R, Looareesuwan S, White NJ, Nosten F: A randomized comparison of artesunate-atovaquone-proguanil versus quinine in treatment for uncomplicated falciparum malaria during pregnancy. $J$ Infect Dis 2005, 192(5):846-853.

57. McGready R, Brockman A, Cho T, Cho D, van Vugt M, Luxemburger C, Chongsuphajaisiddhi T, White NJ, Nosten F: Randomized comparison of mefloquine-artesunate versus quinine in the treatment of multidrugresistant falciparum malaria in pregnancy. Trans $R$ Soc Trop Med Hyg 2000, 94(6):689-693.

58. Quashie NB, Duah NO, Abuaku B, Koram KA: The in-vitro susceptibilities of Ghanaian Plasmodium falciparum to antimalarial drugs. Ann Trop Med Parasitol 2007, 101(5):391-398.

59. Adegnika AA, Breitling LP, Agnandji ST, Chai SK, Schutte D, Oyakhirome S, Schwarz NG, Grobusch MP, Missinou MA, Ramharter M, Issifou S, Kremsner PG: Effectiveness of quinine monotherapy for the treatment of Plasmodium falciparum infection in pregnant women in Lambarene, Gabon. Am J Trop Med Hyg 2005, 73(2):263-266.

60. Piola P, Nabasumba C, Turyakira E, Dhorda M, Lindegardh $N$, Nyehangane D, Snounou G, Ashley EA, McGready R, Nosten F, Guerin PJ: Efficacy and safety of artemether-lumefantrine compared with quinine in pregnant women with uncomplicated Plasmodium falciparum malaria: an open-label, randomised, non-inferiority trial. Lancet Infect Dis 2010, 10(11):762-769.

61. Manyando C, Mkandawire R, Puma L, Sinkala M, Mpabalwani E, Njunju E, Gomes M, Ribeiro I, Walter V, Virtanen M, Schlienger R, Cousin M, Chipimo M, Sullivan FM: Safety of artemether-lumefantrine in pregnant women with malaria: results of a prospective cohort study in Zambia. Malar J 2010, 9:249.

62. Colebunders R, Bahwe Y, Nekwei W, Ryder R, Perriens J, Nsimba K, Turner A, Francis H, Lebughe I, Van der Stuyft P, Piot P: Incidence of malaria and efficacy of oral quinine in patients recently infected with human immunodeficiency virus in Kinshasa, Zaire. J Infect 1990, 21(2):167-173

63. Greenberg AE, Nsa W, Ryder RW, Medi M, Nzeza M, Kitadi N, Baangi M, Malanda N, Davachi F, Hassig SE: Plasmodium Falciparum malaria and perinatally acquired human immunodeficiency virus type 1 infection in Kinshasa, Zaire. A prospective, longitudinal cohort study of 587 children. N Engl J Med 1991, 325(2):105-109.

64. Soyinka JO, Onyeji CO, Omoruyi SI, Owolabi AR, Sarma PV, Cook JM: Effects of concurrent administration of nevirapine on the disposition of quinine in healthy volunteers. J Pharm Pharmacol 2009, 61(4):439-443.

65. Soyinka JO, Onyeji CO, Omoruyi SI, Owolabi AR, Sarma PV, Cook JM: Pharmacokinetic interactions between ritonavir and quinine in healthy volunteers following concurrent administration. Br J Clin Pharmacol 2010, 69(3):262-270.

66. Wanwimolruk S, Kang W, Coville PF, Viriyayudhakorn S, Thitiarchakul S: Marked enhancement by rifampicin and lack of effect of isoniazid on the elimination of quinine in man. Br J Clin Pharmacol 1995, 40(1):87-91.

67. Pukrittayakamee S, Prakongpan S, Wanwimolruk S, Clemens R, Looareesuwan S, White NJ: Adverse effect of rifampin on quinine efficacy in uncomplicated falciparum malaria. Antimicrob Agents Chemother 2003, 47(5):1509-1513.

68. Khoo S, Back D, Winstanley P: The potential for the interactions between antimalarial and antiretroviral drugs. AIDS 2005, 19(10):995-1005.

69. Gasasira AF, Kamya MR, Achan J, Mebrahtu T, Kalyango JN, Ruel T, Charlebois E, Staedke SG, Kekitiinwa A, Rosenthal PJ, Havlir D, Dorsey G: High risk of neutropenia in HIV-infected children following treatment with artesunate plus amodiaquine for uncomplicated malaria in Uganda. Clin Infect Dis 2008, 46(7):985-991.

70. German P, Parikh S, Lawrence J, Dorsey G, Rosenthal PJ, Havlir D, Charlebois E, Hanpithakpong W, Lindegardh N, Aweeka FT: Lopinavir/ ritonavir affects pharmacokinetic exposure of artemether/lumefantrine in HIV-uninfected healthy volunteers. J Acquir Immune Defic Syndr 2009, 51(4):424-429.

71. Lesi A, Meremikwu M: High first dose quinine regimen for treating severe malaria. Cochrane Database Syst Rev 2004, , 3: CD003341.

72. Jones KL, Donegan S, Lalloo DG: Artesunate versus quinine for treating severe malaria. Cochrane Database Syst Rev 2007, , 4: CD005967.

73. Taylor TE, Wills BA, Courval JM, Molyneux ME: Intramuscular artemether vs intravenous quinine: an open, randomized trial in Malawian children with cerebral malaria. Trop Med Int Health 1998, 3(1):3-8.

74. van Hensbroek MB, Onyiorah E, Jaffar S, Schneider G, Palmer A, Frenkel J, Enwere G, Forck S, Nusmeijer A, Bennett S, Greenwood B, Kwiatkowski D: A trial of artemether or quinine in children with cerebral malaria. $N$ Engl J Med 1996, 335(2):69-75.

75. Group TA-QM-aS: A meta-analysis using individual patient data of trials comparing artemether with quinine in the treatment of severe falciparum malaria. Trans R Soc Trop Med Hyg 2001, 95(6):637-650.

76. Aceng JR, Byarugaba JS, Tumwine JK: Rectal artemether versus intravenous quinine for the treatment of cerebral malaria in children in Uganda: randomised clinical trial. BMJ 2005, 330(7487):334.

77. Gomes MF, Faiz MA, Gyapong JO, Warsame M, Agbenyega T, Babiker A, Baiden F, Yunus EB, Binka F, Clerk C, Folb P, Hassan R, Hossain MA, Kimbute O, Kitua A, Krishna S, Makasi C, Mensah N, Mrango Z, Olliaro P, Peto R, Peto TJ, Rahman MR, Ribeiro I, Samad R, White NJ, Study 13 Research Group: Pre-referral rectal artesunate to prevent death and disability in severe malaria: a placebo-controlled trial. Lancet 2009, 373(9663):557-566

78. Achan J, Tibenderana J, Kyabayinze D, Mawejje H, Mugizi R, Mpeka B, Talisuna A, D'Alessandro U: Case management of severe malaria-a forgotten practice: experiences from health facilities in Uganda. PLOS One 2011, 6(3):e17053.

79. Achan J, Byarugaba J, Barennes H, Tumwine JK: Rectal versus intravenous quinine for the treatment of childhood cerebral malaria in Kampala, Uganda: a randomized, double-blind clinical trial. Clin Infect Dis 2007, 45(11):1446-1452.

80. Barennes H, Kailou D, Pussard E, Munjakazi JM, Fernan M, Sherouat $H_{\text {, }}$ Sanda A, Clavier F, Verdier F: [Intrarectal administration of quinine: an early treatment for severe malaria in children?]. Sante 2001, 11(3):145-153.

81. Barennes H, Kahiatani D, Clavier F, Meynard D, Njifountawaouo S, BarennesRasoanandrasana F, Amadou M, Soumana M, Mahamansani A, Granic G, Verdier F: [Rectal quinine, an alternative to parenteral injections for the treatment of childhood malaria. Clinical, parasitological and pharmacological study]. Med Trop (Mars) 1995, 55(4 Suppl):91-94.

82. Barennes H, Kahiatani F, Pussard E, Clavier F, Meynard D, Njifountawouo S, Verdier F: Intrarectal Quinimax (an association of Cinchona alkaloids) for the treatment of Plasmodium falciparum malaria in children in Niger: efficacy and pharmacokinetics. Trans R Soc Trop Med Hyg 1995, 89(4):418-421.

83. Barennes H, Munjakazi J, Verdier F, Clavier F, Pussard E: An open randomized clinical study of intrarectal versus infused Quinimax for the treatment of childhood cerebral malaria in Niger. Trans $R$ Soc Trop Med Hyg 1998, 92(4):437-440. 
84. Barennes H, Balima-Koussoube T, Nagot N, Charpentier JC, Pussard E: Safety and efficacy of rectal compared with intramuscular quinine for the early treatment of moderately severe malaria in children: randomised clinical trial. BMJ 2006, 332(7549):1055-1059.

85. Ndiaye $\mathrm{JL}$, Tine RC, Faye B, Dieyeel HL, Diack PA, Lameyre V, Gaye O, Sow HD: Pilot feasibility study of an emergency paediatric kit for intrarectal quinine administration used by the personnel of communitybased health care units in Senegal. Malar J 2007, 6:152.

86. Thera MA, Keita F, Sissoko MS, Traore OB, Coulibaly D, Sacko M, Lameyre V, Ducret JP, Doumbo O: Acceptability and efficacy of intra-rectal quinine alkaloids as a pre-transfer treatment of non-per os malaria in peripheral health care facilities in Mopti, Mali. Malar J 2007, 6:68.

87. Esamai F, Tenge CN, Ayuo PO, Ong'or WO, Obala A, Jakait B: A randomized open label clinical trial to compare the efficacy and safety of intravenous quinine followed by oral malarone vs. intravenous quinine followed by oral quinine in the treatment of severe malaria. J Trop Pediatr 2005, 51(1):17-24.

88. Peters W: Antimalarial drug resistance: an increasing problem. Br Med Bull 1982, 38(2):187-192.

89. Wernsdorfer WH, Landgraf $B$, Wiedermann G, Kollaritsch H: Chloroquine resistance of Plasmodium falciparum: a biological advantage? Trans $R$ Soc Trop Med Hyg 1995, 89(1):90-91.

90. Bjorkman A, Phillips-Howard PA: The epidemiology of drug-resistant malaria. Trans R Soc Trop Med Hyg 1990, 84(2):177-180

91. Mayxay M, Barends M, Brockman A, Jaidee A, Nair S, Sudimack D, Pongvongsa T, Phompida S, Phetsouvanh R, Anderson T, White NJ, Newton PN: In vitro antimalarial drug susceptibility and pfcrt mutation among fresh Plasmodium falciparum isolates from the Lao PDR (Laos). Am J Trop Med Hyg 2007, 76(2):245-250.

92. Legrand E, Volney B, Meynard JB, Mercereau-Puijalon O, Esterre P: In vitro monitoring of Plasmodium falciparum drug resistance in French Guiana: a synopsis of continuous assessment from 1994 to 2005. Antimicrob Agents Chemother 2008, 52(1):288-298.

93. Tinto H, Rwagacondo C, Karema C, Mupfasoni D, Vandoren W, Rusanganwa E, Erhart A, Van Overmeir C, Van Marck E, D'Alessandro U: Invitro susceptibility of Plasmodium falciparum to monodesethylamodiaquine, dihydroartemisinin and quinine in an area of high chloroquine resistance in Rwanda. Trans $R$ Soc Trop Med Hyg 2006, 100(6):509-514

94. Toure AO, Kone LP, Jambou R, Konan TD, Demba S, Beugre GE, Kone M: [In vitro susceptibility of $P$. falciparum isolates from Abidjan (Cote d'Ivoire) to quinine, artesunate and chloroquine]. Sante 2008, 18(1):43-47.

95. Pradines B, Mabika Mamfoumbi M, Parzy D, Owono Medang M, Lebeau C, Mourou Mbina JR, Doury JC, Kombila M: In vitro susceptibility of Gabonese wild isolates of Plasmodium falciparum to artemether, and comparison with chloroquine, quinine, halofantrine and amodiaquine. Parasitology 1998, 117(Pt 6):541-545.

96. Mutanda LN: Assessment of drug resistance to the malaria parasite in residents of Kampala, Uganda. East Afr Med J 1999, 76(8):421-424.

97. Huttinger F, Satimai W, Wernsdorfer G, Wiedermann U, Congpuong K, Wernsdorfer WH: Sensitivity to artemisinin, mefloquine and quinine of Plasmodium falciparum in northwestern Thailand. Wien Klin Wochenschr 2010, 122(Suppl 3):52-56.

98. Myint HY, Tipmanee P, Nosten F, Day NP, Pukrittayakamee $S$, Looareesuwan S, White $\mathrm{NJ}$ : A systematic overview of published antimalarial drug trials. Trans R Soc Trop Med Hyg 2004, 98(2):73-81.

99. Chongsuphajaisiddhi T, Sabcharoen A, Attanath P: In vivo and in vitro sensitivity of Falciparum malaria to quinine in Thai children. Ann Trop Paediatr 1981, 1(1):21-26.

100. White NJ, Looareesuwan S, Warrell DA, Warrell MJ, Bunnag D, Harinasuta T: Quinine pharmacokinetics and toxicity in cerebral and uncomplicated Falciparum malaria. Am J Med 1982, 73(4):564-572.

101. Looareesuwan S, Charoenpan P, Ho M, White NJ, Karbwang J, Bunnag D, Harinasuta T: Fatal Plasmodium falciparum malaria after an inadequate response to quinine treatment. J Infect Dis 1990, 161(3):577-580.

102. Newton PN, Ward S, Angus BJ, Chierakul W, Dondorp A, Ruangveerayuth R, Silamut K, Teerapong P, Suputtamongkol Y, Looareesuwan S, White NJ: Early treatment failure in severe malaria resulting from abnormally low plasma quinine concentrations. Trans R Soc Trop Med Hyg 2006, 100(2):184-186.
103. Pukrittayakamee S, Wanwimolruk S, Stepniewska K, Jantra A, Huyakorn S, Looareesuwan S, White NJ: Quinine pharmacokinetic-pharmacodynamic relationships in uncomplicated falciparum malaria. Antimicrob Agents Chemother 2003, 47(11):3458-3463.

104. Onwujekwe O, Kaur H, Dike N, Shu E, Uzochukwu B, Hanson K, Okoye V, Okonkwo P: Quality of anti-malarial drugs provided by public and private healthcare providers in south-east Nigeria. Malar J 2009, 8:22.

105. Gaudiano MC, Di Maggio A, Cocchieri E, Antoniella E, Bertocchi P, Alimonti S, Valvo L: Medicines informal market in Congo, Burundi and Angola: counterfeit and sub-standard antimalarials. Malar J 2007, 6:22.

106. Basco LK: Molecular epidemiology of malaria in cameroon. XX. Experimental studies on various factors of in vitro drug sensitivity assays using fresh isolates of Plasmodium falciparum. Am J Trop Med Hyg 2004, 70(5):474-480.

107. Lon CT, Tsuyuoka R, Phanouvong S, Nivanna N, Socheat D, Sokhan C, Blum N, Christophel EM, Smine A: Counterfeit and substandard antimalarial drugs in Cambodia. Trans $R$ Soc Trop Med Hyg 2006, 100(11):1019-1024.

108. Kayumba PC, Risha PG, Shewiyo D, Msami A, Masuki G, Ameye D, Vergote G, Ntawukuliryayo JD, Remon JP, Vervaet C: The quality of essential antimicrobial and antimalarial drugs marketed in Rwanda and Tanzania: influence of tropical storage conditions on in vitro dissolution. J Clin Pharm Ther 2004, 29(4):331-338.

109. Metzger W, Mordmuller B, Graninger W, Bienzle U, Kremsner PG: High efficacy of short-term quinine-antibiotic combinations for treating adult malaria patients in an area in which malaria is hyperendemic. Antimicrob Agents Chemother 1995, 39(1):245-246.

doi:10.1186/1475-2875-10-144

Cite this article as: Achan et al:: Quinine, an old anti-malarial drug in a modern world: role in the treatment of malaria. Malaria Journal 2011 10:144

\section{Submit your next manuscript to BioMed Central and take full advantage of:}

- Convenient online submission

- Thorough peer review

- No space constraints or color figure charges

- Immediate publication on acceptance

- Inclusion in PubMed, CAS, Scopus and Google Scholar

- Research which is freely available for redistribution

Submit your manuscript at www.biomedcentral.com/submit
C) Biomed Central 